\title{
Argyrophil cell density in the oxyntic mucosa is higher in female than in male morbidly obese patients
}

\author{
F.A.N. Maksud ${ }^{1,3}$, A.M. Kakehasi ${ }^{1}$ and A.J.A. Barbosa ${ }^{1,2}$ \\ ${ }^{1}$ Laboratório de Patologia Digestiva e Neuroendócrina, Faculdade de Medicina, Universidade Federal de Minas Gerais, \\ Belo Horizonte, MG, Brasil \\ ${ }^{2}$ Instituto Alfa de Gastroenterologia, Belo Horizonte, MG, Brasil \\ ${ }^{3}$ Faculdade de Medicina, Universidade Federal de Ouro Preto, Ouro Preto, MG, Brasil
}

\begin{abstract}
Obesity is a multifactorial disorder often associated with many important diseases such as diabetes, hypertension and other metabolic syndrome conditions. Argyrophil cells represent almost the total population of endocrine cells of the human gastric mucosa and some reports have described changes of specific types of these cells in patients with obesity and metabolic syndrome. The present study was designed to evaluate the global population of argyrophil cells of the gastric mucosa of morbidly obese and dyspeptic non-obese patients. Gastric biopsies of antropyloric and oxyntic mucosa were obtained from 50 morbidly obese patients (BMI >40) and 50 non-obese patients (17 dyspeptic overweight and 33 lean individuals) and processed for histology and Grimelius staining for argyrophil cell demonstration. Argyrophil cell density in the oxyntic mucosa of morbidly obese patients was higher in female $\left(238.68 \pm 83.71 \mathrm{cells} / \mathrm{mm}^{2}\right)$ than in male patients $\left(179.31 \pm 85.96 \mathrm{cells} / \mathrm{mm}^{2}\right)$ and also higher in female $\left(214.20 \pm 50.38\right.$ cells $\left./ \mathrm{mm}^{2}\right)$ than in male $\left(141.90 \pm 61.22 \mathrm{cells} / \mathrm{mm}^{2}\right)$ morbidly obese patients with metabolic syndrome $(P=0.01$ and $P=0.02$, respectively). In antropyloric mucosa, the main difference in argyrophil cell density was observed between female morbidly obese patients with $\left(167.00 \pm 69.30 \mathrm{cells} / \mathrm{mm}^{2}\right)$ and without $(234.00 \pm 69.54$ cells $\left./ \mathrm{mm}^{2}\right)$ metabolic syndrome $(P=0.001)$. In conclusion, the present results show that the number of gastric argyrophil cells could be under gender influence in patients with morbid obesity. In addition, gastric argyrophil cells seem to behave differently among female morbidly obese patients with and without metabolic syndrome.
\end{abstract}

Key words: Argyrophil cells; Endocrine cells; Obesity; Gastric mucosa; Metabolic syndrome

\section{Introduction}

The etiology of obesity, a serious medical condition that affects an increasingly large number of individuals, is unknown although it is believed to be multifactorial (1). Some of the gastrointestinal regulatory peptides have been reported to be associated with satiety, and the 28-amino acid peptide ghrelin, mainly produced by neuroendocrine cells of the gastric mucosa, has been associated with a positive metabolic balance (2). Neuroendocrine cells producing these peptides are present in the different segments of the gut. Among the segments of the human gastrointestinal tract, the oxyntic mucosa of the stomach has a high concentration of these cells, which can be easily identified in full by the Grimelius-staining method (3).

Over the last three decades there has been a major worldwide increase in the incidence of metabolic disturbances that characterize the so-called metabolic syndrome
(MS) $(4,5)$. This phenomenon appears to be linked to the significant increase of obesity in the population. In addition, abdominal obesity and MS have been correlated with a differential serum concentration of gastrointestinal peptides, including ghrelin, gastrin, gastric inhibitory peptide, and glucagon-like peptide-1 (6). Since our previous results have shown that the specific type of ghrelin-producing cells of the gastric body behaved differently in patients with morbid obesity (7), we decided to study the full population of argyrophil cells from the body and antropyloric regions of the stomach of morbidly obese patients with and without MS.

\section{Material and Methods}

Three groups of patients were studied: a) 50 obese patients (38 women, 12 men, mean age: 35.4 years, BMI 
$>40$ ) candidates for bariatric surgery, 21 (42\%) of whom had MS. Metabolic syndrome was defined according to the International Diabetes Federation (4) and the National Cholesterol Education Program (5) criteria: all patients had triglycerides $\geqslant 150 \mathrm{mg} / \mathrm{dL}$ or reduced HDL cholesterol, systolic blood pressure $\geqslant 130$ or diastolic blood pressure $\geqslant 85 \mathrm{mmHg}$, and type 2 diabetes mellitus or hyperglycemia (fasting plasma glucose $\geqslant 100 \mathrm{mg} / \mathrm{dL}$ ) in addition to large waist circumference; b) 17 overweight dyspeptic patients (14 women, 3 men, mean age: 47.8 years, $25<\mathrm{BMI}<30$ ), and c) 33 lean dyspeptic patients (18 women, 15 men, mean age: 41.7 years, BMI <25) subjected to upper digestive endoscopy due to dyspeptic complaints and taking no medications.

All patients were retrospectively and consecutively selected at the General Hospital Gastroenterology Unit, with patients presenting peptic ulcer or neoplastic lesions being excluded. In addition, patients with atrophic body gastritis and histology suspected to be of autoimmune etiology were also excluded. The clinical and laboratory data of all patients were obtained from the hospital medical records. The Institutional Ethics Committee of the Federal University of Minas Gerais approved the study protocol, and written informed consent was obtained from all participants.

Six tissue specimens of endoscopic gastric biopsies were obtained by the same endoscopist: 4 from the oxyntic mucosa and 2 from the antral mucosa. The biopsy specimens were fixed in $4 \%$ formaldehyde and embedded in paraffin, and 4- $\mu \mathrm{m}$ sections from each specimen were stained with hematoxylin and eosin for histology, Giemsa for histological evaluation of $H$. pylori infection, and the Grimelius technique for staining of argyrophil cells (8). Argyrophil cell density was evaluated on acquired microscopic digital images (Axiocam camera and KS 300 digital system, Zeiss, Germany) in six consecutive 0.21-mm wide columns containing the full mucosa thickness at 400X magnification. The results are reported as the average number of cells $/ \mathrm{mm}^{2}$.

Statistical analysis was carried out using Epi-Info version 6.04 and GraphPad Prism version 5.01 softwares. Chi-square and Fisher tests were used for categorical comparisons and the Student $t$-test was used to compare means between groups. The Kruskal-Wallis or MannWhitney test was used to compare continuous vs categorical variables. A $P$ value $<0.05$ was considered to be statistically significant.

\section{Results}

The frequency of chronic gastritis was similar $(\mathrm{P}=$ 0.36) among obese, $n=27$ (54\%), overweight, $n=12$ $(70.6 \%)$ and lean, $n=20(60.6 \%)$ patients, and Helicobacter pylori infection was present in 25 (50\%), 8 $(47 \%)$ and $22(66.6 \%)$ of the patients in each group. Argyrophil cells stained by the Grimelius technique were demonstrated throughout the body and antropyloric mucosa of the stomach. At first glance, the histological examination showed no quantitative differences in the population of argyrophil cells among the three groups of patients studied (Figure 1). This general observation was confirmed by cell counts, i.e., obese, overweight and lean patients presented no differences in argyrophil cell densities in oxyntic mucosa, with respective values of $225.61 \pm 86.95,239.94 \pm 67.67$, and $240.36 \pm 85.98$ cells $/ \mathrm{mm}^{2}(P=0.38)$. Similar results were observed in the antropyloric mucosa with $212.24 \pm 83.05,206.92 \pm$ 70.67 and $201.98 \pm 62.40$ cells $/ \mathrm{mm}^{2}$, respectively $(P=$ $0.45)$. Conversely, the argyrophil cell density in the oxyntic mucosa of morbidly obese patients was higher $(P=0.01)$ in females (mean $238.68 \pm 83.71$ cells $/ \mathrm{mm}^{2}$ ) than in males (mean $179.31 \pm 85.96$ cells $/ \mathrm{mm}^{2}$ ). There were no differences in argyrophil cell density in the antropyloric mucosa between morbidly obese male and female patients, with respective mean values of $208.24 \pm$ 76.48 and $219.48 \pm 106.41$ cells $/ \mathrm{mm}^{2}(P=1.00)$.

Among the 50 morbidly obese patients, 21 (42\%) had MS (15 females and 6 males) and 29 (58\%) did not present criteria for the diagnosis of MS (24 females and 5 males). In the oxyntic mucosa, argyrophil cell density was similar $(P=0.23)$ for females with and without MS, with respective mean values of $214.20 \pm 50.58$ vs $254.00 \pm$ 96.89 cells $/ \mathrm{mm}^{2}$. The same result was observed for male patients with and without MS, with respective mean values of $141.90 \pm 61.33$ vs $224.20 \pm 95.69 \mathrm{cells} / \mathrm{mm}^{2}$ $(P=0.14)$. On the other hand, morbidly obese female patients with MS showed higher $(P=0.02)$ argyrophil cell
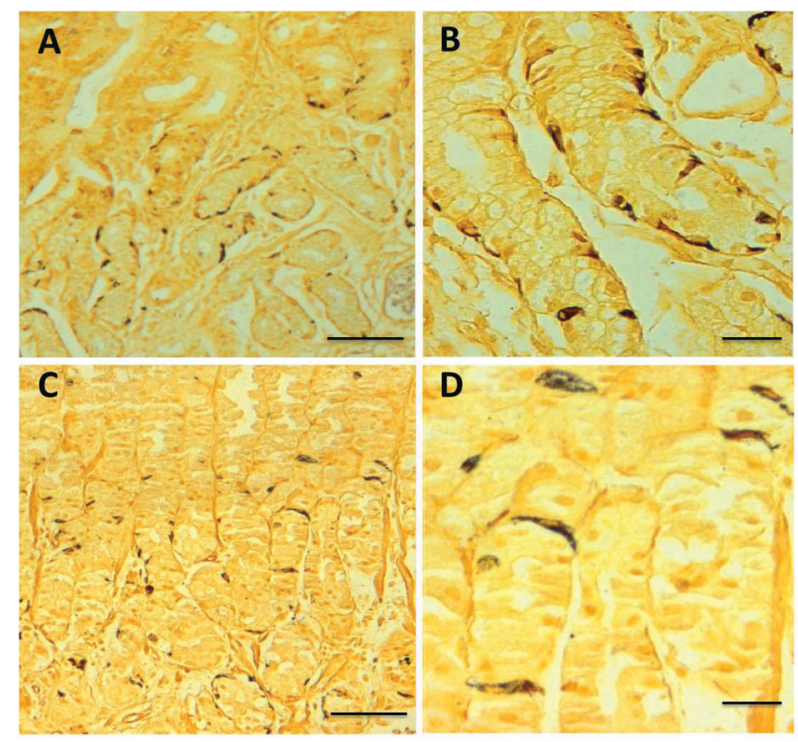

Figure 1. Argyrophil cells stained by the Grimelius technique in the antropyloric $(A$ and $B)$ and oxyntic gastric mucosa $(C$ and $D)$ of morbidly obese patient without metabolic syndrome. Bars: 50 $\mu \mathrm{m}(A$ and $C)$, and $10 \mu \mathrm{m}(B$ and $D)$. 
density in the oxyntic mucosa (mean 214.20 \pm 50.38 cells $/ \mathrm{mm}^{2}$ ) than obese males with MS (mean $141.90 \pm$ 61.22 cells $/ \mathrm{mm}^{2}$ ). Female and male patients without MS did not show a difference in argyrophil cell density in the oxyntic mucosa (Figure 2).

In the antropyloric mucosa the main difference in argyrophil cell density was observed only between morbidly obese female patients with and without MS, with respective mean values of $167.00 \pm 69.30$ and $234.00 \pm$ 69.54 cells $/ \mathrm{mm}^{2}(P=0.001)$. In contrast to the oxyntic mucosa, the density of argyrophil cells in the antropyloric mucosa did not differ between morbidly obese female and male patients with and without MS (Figure 3).

\section{Discussion}

The neuroendocrine cells of the gastrointestinal mucosa differ in type and distribution according to the different regions of the gut. The behavioral differences of the argyrophil cell number found in the gastric mucosa of obese patients are not at all surprising. The literature reports data showing differences in plasma concentration of regulatory peptides in obese patients with and without MS and according to gender (9).

Metabolic syndrome is characterized by abnormalities in blood pressure, lipid and glycemic homeostasis, which together lead to greater cardiovascular morbidity and mortality $(4,5)$. The underlying cause of MS is still only partially understood but both insulin resistance and central obesity are considered to be significant factors.

\section{Oxyntic mucosa}

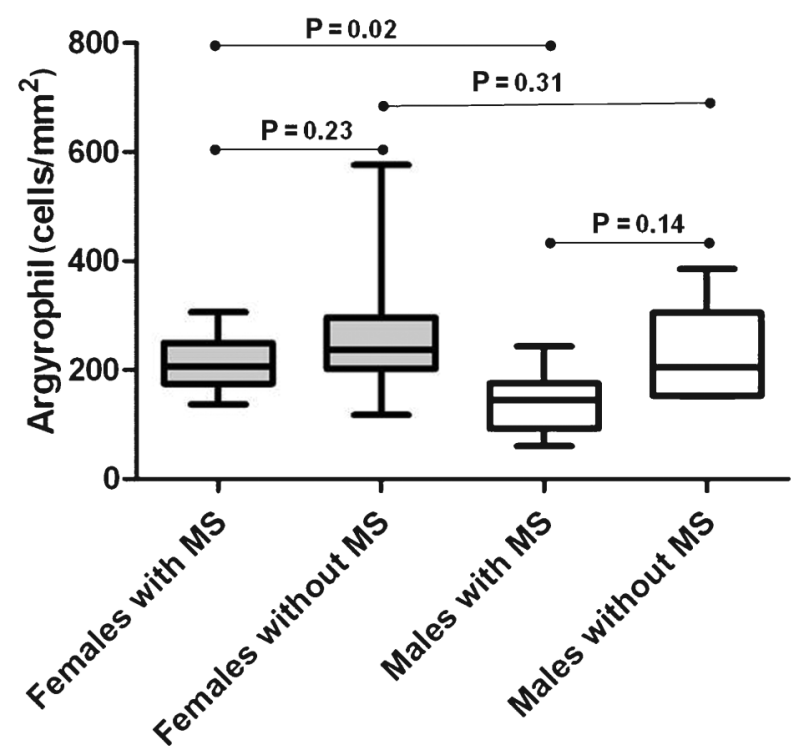

Figure 2. Argyrophil cell density in the oxyntic mucosa of female and male morbidly obese patients with and without metabolic syndrome (MS).

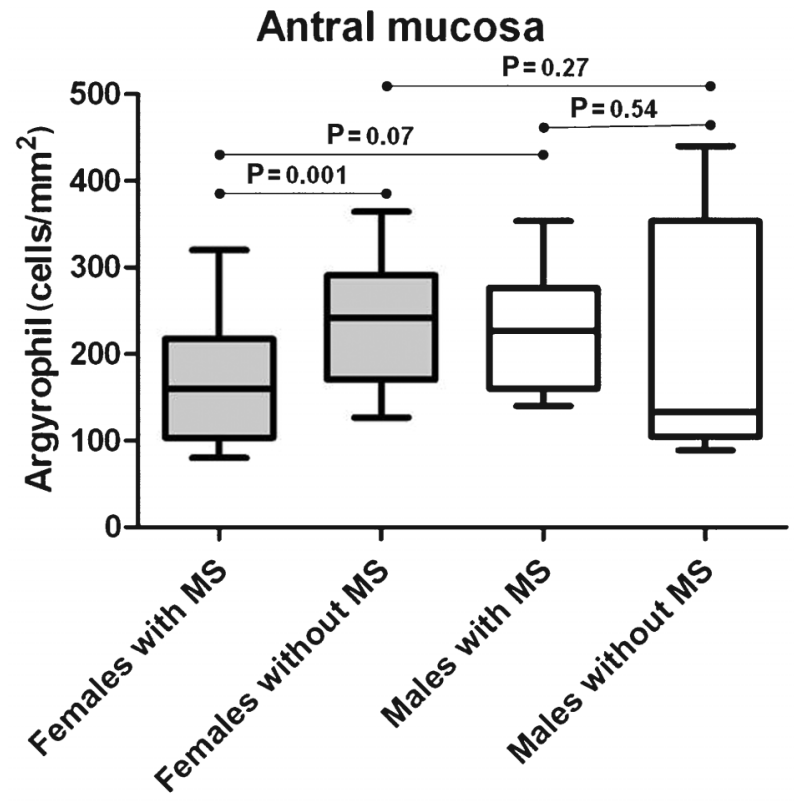

Figure 3. Argyrophil cell density in the antropyloric mucosa of female and male morbidly obese patients with and without metabolic syndrome (MS).

Recently, several investigators have shown that the changes found in MS are related to different neuroendocrine axes. Leptin, considered to be a marker of adiposity and to be associated with insulin sensitivity and the gonadotrophin axis, has been shown to be elevated in obese patients, although resistance to a central action of this hormone occurs in these cases (9). Abdominal obesity might be associated with a state of subclinical hypercortisolism secondary to the activation of the corticotrophin axis, and cortisol appears to play a role in regulating the circadian fluctuations of brain-gut peptides and the cell cycle of the gastrointestinal mucosa $(10,11)$.

The argyrophil cells present in the oxyntic gastric mucosa are of a closed type without contact with the gastric lumen. The most numerous endocrine argyrophil cells in oxyntic mucosa are enterochromaffin-like cells that produce histamine in addition to peptide products not yet completely known. The other cells present in this area are somatostatin-producing $D$ cells, serotonin-producing endocrine cells, ghrelin-producing cells described as A/Xlike, and other less well-known cell types. On the other hand, most of the endocrine cells of the antropyloric mucosa are of the open type and are represented by gastrin-producing $G$ cells, somatostatin-producing $D$ cells and serotonin-producing endocrine cells (12). Very little is known about the behavior of the endocrine cells of the antropyloric mucosa in relation to obesity and MS. Recently, a small number of investigators have attempted to relate gastrin to the higher incidence of cancer in obese patients (13). Similarly, the lack of gastrin in knockout 
mice was related to the increase of adipogenesis and hyperinsulinemia (14). Finally, changes in the distribution and frequency of specific types of gastric endocrine cells have been described in the gastrointestinal tract in different pathologic conditions such as hypergastrinemic states and in $H$. pylori-associated duodenal ulcer patients (15-17). However, the present study seems to be the first to report differential quantitative changes of the gastric argyrophil cell population in morbidly obese female and

\section{References}

1. Pereira-Lancha LO, Campos-Ferraz PL, Lancha AH Jr. Obesity: considerations about etiology, metabolism, and the use of experimental models. Diabetes Metab Syndr Obes 2012; 5: 75-87.

2. Ariyasu H, Takaya K, Tagami T, Ogawa $\mathrm{Y}$, Hosoda K, Akamizu T, et al. Stomach is a major source of circulating ghrelin, and feeding state determines plasma ghrelin-like immunoreactivity levels in humans. J Clin Endocrinol Metab 2001; 86: 4753-4758, doi: 10.1210/jc.86.10.4753.

3. Grimelius L, Wilander E. Silver stains in the study of endocrine cells of the gut and pancreas. Invest Cell Pathol 1980; 3: 3-12.

4. International Diabetes Federation. The IDF consensus worldwide definition of the metabolic syndrome. http://www.idf.org/ webdata/docs/IDF_Metasybdrome_definition.pdf. Accessed May 2012

5. Grundy SM, Brewer HB Jr, Cleeman JI, Smith SC Jr, Lenfant C. Definition of metabolic syndrome: Report of the National Heart, Lung, and Blood Institute/American Heart Association conference on scientific issues related to definition. Circulation 2004; 109: 433-438, doi: 10.1161/ 01.CIR.0000111245.75752.C6.

6. Zwirska-Korczala K, Konturek SJ, Sodowski M, Wylezol M, Kuka D, Sowa P, et al. Basal and postprandial plasma levels of PYY, ghrelin, cholecystokinin, gastrin and insulin in women with moderate and morbid obesity and metabolic syndrome. J Physiol Pharmacol 2007; 58 (Suppl 1): 13-35.

7. Maksud FAN, Alves JS, Diniz MTC, Barbosa AJA. Density of ghrelin-producing cells is higher in the gastric mucosa of morbidly obese patients. Eur J Endocrinol 2011; 165: 57-62, doi: 10.1530/EJE-11-0201.

8. Grimelius L. A silver nitrate stain for alpha- 2 cells in human pancreatic islets. Acta Soc Med Ups 1968; 73: 243-270. male patients and in female patients with and without metabolic syndrome.

\section{Acknowledgments}

The authors thank Dr. Eugenio M.A. Goulard for assistance with the statistical analysis and Ms. Luciene S.P. Faria for technical assistance. Research supported by CNPq and FAPEMIG.

9. Matos AFG, Moreira RO, Guedes EP. Neuroendocrinology of the metabolic syndrome. Arq Bras Endocrinol Metab 2003; 47: 410-420, doi: 10.1590/S0004-27302003000400013.

10. Bjorntorp P, Rosmond R. Obesity and cortisol. Nutrition 2000; 16: 924-936, doi: 10.1016/S0899-9007(00)00422-6.

11. Leal AM, Moreira AC. Food and the circadian activity of the hypothalamic-pituitary-adrenal axis. Braz J Med Biol Res 1997; 30: 1391-1405, doi: 10.1590/S0100-879X1997001200003.

12. Solcia E, Rindi G, Buffa R, Fiocca R, Capella C. Gastric endocrine cells: types, function and growth. Regul Pept 2000; 93: 31-35, doi: 10.1016/S0167-0115(00)00175-0.

13. D'Onghia V, Leoncini R, Carli R, Santoro A, Giglioni S, Sorbellini $F$, et al. Circulating gastrin and ghrelin levels in patients with colorectal cancer: correlation with tumour stage, Helicobacter pylori infection and BMI. Biomed Pharmacother 2007; 61: 137-141, doi: 10.1016/j.biopha.2006.08.007.

14. Cowey SL, Quast M, Belalcazar LM, Wei J, Deng X, Given $\mathrm{R}$, et al. Abdominal obesity, insulin resistance, and colon carcinogenesis are increased in mutant mice lacking gastrin gene expression. Cancer 2005; 103: 2643-2653, doi: 10.1002/cncr.21094.

15. Feurle GE. Argyrophil cell hyperplasia and a carcinoid tumour in the stomach of a patient with sporadic ZollingerEllison syndrome. Gut 1994; 35: 275-277, doi: 10.1136/ gut.35.2.275.

16. Belaiche J, Delwaide J, Vivario M, Gast P, Louis E, Boniver J. Fundic argyrophil cell hyperplasia in atrophic gastritis: a search for a sensitive diagnostic method. Acta Gastroenterol Belg 1993; 56: 11-17.

17. Eissele R, Brunner G, Simon B, Solcia E, Arnold R. Gastric mucosa during treatment with lansoprazole: Helicobacter pylori is a risk factor for argyrophil cell hyperplasia. Gastroenterology 1997; 112: 707-717, doi: 10.1053/gast.1997.v112.pm9041231. 